\title{
Assessment of Supply Chain Energy Efficiency Potentials: A U.S. Case Study
}

\author{
Eric Masanet, Klaas Jan Kramer, Gregory Homan, Richard Brown, and Ernst Worrell
}

\begin{abstract}
This paper summarizes a modeling framework that characterizes the key underlying technologies and processes that contribute to the supply chain energy use and greenhouse gas (GHG) emissions of a variety of goods and services purchased by U.S. consumers. The framework couples an input-output supply chain modeling approach with "bottom-up" fuel end use models for individual IO sectors. This fuel end use modeling detail allows energy and policy analysts to better understand the underlying technologies and processes contributing to the supply chain energy and GHG "footprints" of goods and services. To illustrate the policy-relevance of this approach, a case study was conducted to estimate achievable household GHG footprint reductions associated with the adoption of best practice energy-efficient supply chain technologies.
\end{abstract}

Index Terms — Life-cycle assessment, energy efficiency, supply chain modeling, input-output analysis.

\section{INTRODUCTION}

$\mathrm{T}$ HERE is growing interest in the development of tools and methods for calculating the so-called "carbon footprint" associated with household consumption. The household carbon footprint includes both direct emissions from household energy use and transportation, and indirect supply chain emissions arising from the production of goods and services consumed by a household. Weber and Matthews [1] estimated that the total carbon footprint of U.S. households amounted to roughly 5700 megatons (Mt) in 2004. ${ }^{1}$ Roughly a third of this amount was estimated to be attributable to supply chain emissions.

This paper summarizes recent exploratory research by Lawrence Berkeley National Laboratory (LBNL) to develop a supply chain energy use and greenhouse gas (GHG) footprint analysis framework that couples bottom-up and input-output (IO) modeling approaches to estimate the supply chain energy and GHG footprints of U.S households.

The resulting model provides greater bottom-up detail than existing tools, which should allow energy and policy analysts to better understand the underlying technologies and processes contributing to the energy and GHG footprints of U.S. households. This detail also facilitates the analysis of specific technology improvement options for reducing the energy and GHG footprints of U.S. residents.

\section{MODELING APPROACH}

To estimate the annual GHG emissions generated by the purchase of various goods and services by U.S. households, LBNL relied on an established modeling approach that couples IO economic data with IO sector-level data on energy use and GHG emissions.

Simply described, such models have two primary structural components. The first component is an IO total requirements matrix that quantifies the economic interdependencies of all key sectors in an economy. For a unit of economic output from one sector, the total requirements matrix allows one to estimate the corresponding economic inputs to that sector that are required from all other sectors in the economy. The second component is a set of coefficients that quantify the average fuel use and GHG emissions per unit of economic output for each sector in the economy. By coupling these coefficients with the data in the

This work was performed by Lawrence Berkeley National Laboratory for the California Energy Commission's PIER Program under contract number UC 500-02-004, work authorization number MR-069, through the U.S. Department of Energy under Contract No. DE-AC02-05CH11231. The views and opinions of authors expressed herein do not necessarily state or reflect those of the United States Government or any agency thereof, or The Regents of the University of California.

Eric Masanet (ermasanet@lbl.gov), Gregory Homan (gkhoman@lbl.gov), and Richard Brown (rebrown@lbl.gov) are with the Environmental Energy Technologies Division at Lawrence Berkeley National Laboratory, Berkeley, California, 94720 USA.

Klaas Jan Kramer (info@kjkramerconsulting.com) is with KJKramer Consulting, Groningen, The Netherlands.

Ernst Worrell (e.worrell@ecofys.nl) is with Ecofys and the Department of Science, Technology and Society at Utrecht University, Utrecht, The Netherlands. 
total requirements matrix, it is possible to estimate the economy-wide energy use and GHG emissions associated with a unit of economic output from any sector in the economy.

This general approach gained traction in the United States in the 1970s in the field of net energy analysis [3]. More recent work has extended this approach to include other environmental impact categories (e.g., criteria air pollutants and toxic emissions), most notably by Carnegie Mellon University (CMU) in the development of its widely-used Economic Input-Output Life-Cycle Assessment (EIO-LCA) tool [4, 5].

The IO-based supply chain modeling framework described in this paper expands upon previous work by incorporating fuel end use coefficients for many of the economic sectors in traditional IO models. A fuel end use is defined as an energy-consuming technology or process within a given sector, such as lighting and heating, ventilation, and air conditioning (HVAC) in the commercial sector or motors, steam systems, and process heaters in the industrial sector.

The research team used the 2002 U.S. benchmark total requirements matrix to model IO transactions across the supply chain for 426 economic sectors. This matrix was developed by the U.S. Bureau of Economic Analysis [6] and is the most recent benchmark matrix available.

The aggregate IO fuel use coefficients were based largely on fuel use data that were compiled by Carnegie Mellon University (CMU) in the development of its 2002 U.S. benchmark EIO-LCA model [7]. The research team used the CMU data to construct fuel use coefficients for all 426 sectors in the 2002 benchmark total requirements matrix across five different fuel categories: (1) purchased electricity; (2) natural gas; (3) coal; (4) petroleum; and (5) biomass/wastes/other.

Next, the research team compiled available information to characterize the average fuel end use breakdown for each IO sector for which such data existed. The research team utilized a variety of resources in developing its fuel end use breakdowns, including: (1) data from the U.S. Department of Energy (DOE) surveys [8, 9]; (2) data on farm energy use in various agricultural IO sectors from Brown and Elliott [10]; (3) data on water and sewage treatment energy use from Brown et al. [11]; and (4) various industrial process and building energy models developed by LBNL in prior work over the past decade (see for example [12]).

In total, the above approach allowed the research team to estimate important fuel end uses in 397 of the 426 IO sectors in the 2002 benchmark total requirements matrix. The fuel end use modeling detail is summarized in Table 1.

Supply chain GHG emissions arising from fossil fuel end uses were estimated using an average GHG emission factor for each fuel type from the IPCC's GHG emission factor database [13].

Non-energy sources of GHG emissions in the supply chain include such sources as landfill methane emissions and processrelated emissions from steel, cement, and semiconductor manufacture. To estimate these emissions, the research team relied on IO sector level non-energy GHG emission data from the U.S. Environmental Protection Agency's 2002 national GHG emissions inventory [14].

A full description of the modeling methodology, data sources, and key equations is available in [15].

TABLE 1: SUMMARY OF FUEL END USE COEFFICIENTS BY IO SECTOR CATEGORY AND FUEL TYPE

\begin{tabular}{|l|l|}
\hline \multicolumn{2}{|l|}{ Manufacturing (electricity, natural gas, coal, and petroleum) } \\
\hline Conventional Boiler Use & Facility HVAC \\
\hline $\begin{array}{l}\text { CHP and/or Cogeneration } \\
\text { Process }\end{array}$ & Facility Lighting \\
\hline Process Heating & Onsite Transportation \\
\hline $\begin{array}{l}\text { Process Cooling and } \\
\text { Refrigeration }\end{array}$ & $\begin{array}{l}\text { Conventional Electricity } \\
\text { Generation }\end{array}$ \\
\hline Machine Drive Commercial (electricity) \\
\hline Electro-Chemical Processes & Other \\
\hline \multicolumn{2}{|l|}{ Cooking } \\
\hline Space Heating & Refrigeration \\
\hline Cooling & Office Equipment \\
\hline Ventilation & Computers \\
\hline Water Heating & Other \\
\hline Lighting
\end{tabular}

\begin{tabular}{|l|l|}
\hline \multicolumn{2}{|c|}{ Commercial (natural gas) } \\
\hline Space Heating & Cooking \\
\hline Water Heating & Other \\
\hline \multicolumn{2}{|c|}{ Agriculture (electricity, natural gas, petroleum) } \\
\hline Motors & Machinery \\
\hline Lighting & Other \\
\hline Onsite transport & \\
\hline \multicolumn{2}{|c|}{ Water treatment (electricity) } \\
\hline Pumping systems & Other \\
\hline
\end{tabular}

\section{CASE STUDY}

To illustrate the policy-relevance of the modeling framework, a case study was conducted that analyzed achievable U.S. 
household GHG footprint reductions associated with the adoption of best practice energy-efficient supply chain technologies.

To estimate a baseline average annual supply chain GHG footprint, the research team coupled the modeling framework discussed in Section II with a prototypical annual portfolio of purchased goods and services based on the U.S. Bureau of Labor Statistics' Consumer Expenditure Survey (CES) [16]. The CES compiles data on average U.S. consumer spending for hundreds of different goods and services based on a combination of weekly diaries and quarterly telephone interviews. The research team used 2002 average annual spending data for U.S. households in its analysis, and converted the 2002 national average CES data into 2002 national average producer prices.

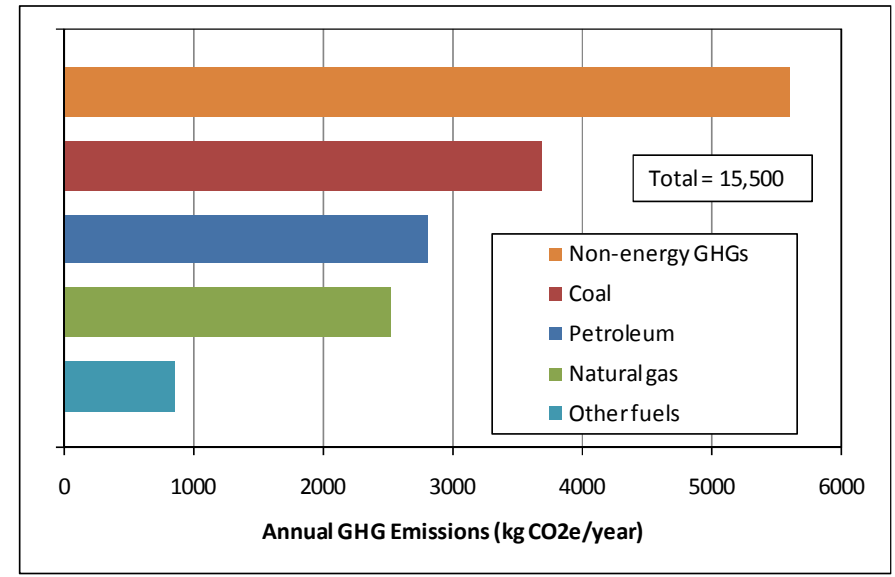

FIGURE 1: SUMMARY OF ESTIMATED 2002 SUPPLY CHAIN GHG

EMISSIONS FOR THE AVERAGE U.S. HOUSEHOLD BY SOURCE

The estimated 2002 supply chain GHG emissions attributable to the purchase of goods and services by the average U.S. household are presented in Figure 1 by emissions source. The results in Figure 1 agree favorably with the results of a recent U.S. national carbon footprint study [1]. However, the most novel feature of the supply chain modeling framework developed in this project is its ability to disaggregate energy-related supply chain GHG emissions by fuel end use as described in Section II. By way of example, Tables 2 and 3 summarize the estimated average supply chain GHG emissions attributable to electricity and natural gas for key fuel end uses in aggregate IO sectors.

The results in Table 2 suggest that supply chain electricity use accounts for around one-quarter of the 2002 supply chain GHG emissions footprint of the average U.S. household. The end use summary suggests that the vast majority of these electricityrelated emissions $(87 \%)$ are attributable to end uses in the manufacturing and commercial sectors.

Moreover, roughly two-thirds of electricity-related emissions are estimated to be attributable to three broad end uses: motor systems, lighting, and HVAC systems. Thus, it is likely that these end uses represent important efficiency opportunities for reducing the supply chain GHG emissions footprint of U.S. households. Furthermore, the results in Table 1 suggest that around $80 \%$ of all supply chain electricity-related GHG emissions could be characterized into meaningful end uses (i.e., not generic "other" categories).

Table 3 summarizes the end use estimates for average natural gas-related supply chain GHG emissions. It was estimated that process heating, HVAC, and steam system end uses account for around one-half of natural gas related emissions. Combined, the manufacturing, commercial, and power sectors accounted for around 90\% of estimated natural gas-related GHG emissions. Similar fuel end use breakdowns were performed for coal, petroleum, and other fuels for the manufacturing, commercial, agricultural, electric power, water treatment, and transportation sectors. 
TABLE 2: ESTIMATED 2002 SUPPLY CHAIN ELECTRICITY-RELATED GHG EMISSIONS PER HOUSEHOLD BY END USE

\begin{tabular}{|c|c|c|c|}
\hline Sector & End Use & $\begin{array}{l}\mathrm{kg} \\
\mathrm{CO} \mathrm{e} \text { e/year }\end{array}$ & $\begin{array}{l}\% \text { of } \\
\text { Total }\end{array}$ \\
\hline \multirow[t]{8}{*}{ Manufacturing } & Machine Drives & 751 & $20 \%$ \\
\hline & Process Heating & 147 & $4 \%$ \\
\hline & Process Cooling & 130 & $3 \%$ \\
\hline & Facility HVAC & 127 & $3 \%$ \\
\hline & Electro-Chemical Processes & 114 & $3 \%$ \\
\hline & Facility Lighting & 99 & $3 \%$ \\
\hline & End Use Not Reported & 52 & $1 \%$ \\
\hline & Other Facility Support/Uses & 41 & $1 \%$ \\
\hline \multirow[t]{10}{*}{ Commercial } & Lighting & 606 & $16 \%$ \\
\hline & Cooling & 268 & $7 \%$ \\
\hline & Ventilation & 251 & $7 \%$ \\
\hline & Refrigeration & 206 & $5 \%$ \\
\hline & Other & 200 & $5 \%$ \\
\hline & Computers & 111 & $3 \%$ \\
\hline & Space Heating & 80 & $2 \%$ \\
\hline & Office Equipment & 42 & $1 \%$ \\
\hline & Water Heating & 40 & $1 \%$ \\
\hline & Cooking & 28 & $1 \%$ \\
\hline \multirow[t]{4}{*}{ Agricultural } & Other & 259 & $7 \%$ \\
\hline & Motors & 33 & $1 \%$ \\
\hline & Lighting & 15 & $0 \%$ \\
\hline & Machinery & 7 & $0 \%$ \\
\hline \multirow[t]{2}{*}{$\begin{array}{l}\text { Water } \\
\text { treatment }\end{array}$} & Motor systems (pumps) & 8 & $0 \%$ \\
\hline & Other & 1 & $0 \%$ \\
\hline Unclassified & Unclassified & 165 & $4 \%$ \\
\hline \multicolumn{2}{|c|}{ Total for all sectors } & 3782 & $100 \%$ \\
\hline
\end{tabular}

TABLE 3: ESTIMATED 2002 SUPPLY CHAIN NATURAL GASRELATED GHG EMISSIONS PER HOUSEHOLD BY END USE

\begin{tabular}{|c|c|c|c|}
\hline Sector & End Use & $\begin{array}{l}\text { kg } \\
\text { co2e/year }\end{array}$ & $\begin{array}{l}\% \text { of } \\
\text { Total }\end{array}$ \\
\hline \multirow[t]{10}{*}{ Manufacturing } & Process Heating & 411 & $16 \%$ \\
\hline & Conventional Boiler Use & 253 & $10 \%$ \\
\hline & Combined heat and power & 134 & $5 \%$ \\
\hline & Facility HVAC & 59 & $2 \%$ \\
\hline & End Use Not Reported & 22 & $1 \%$ \\
\hline & Machine Drive-Total & 21 & $1 \%$ \\
\hline & $\begin{array}{l}\text { Conventional Electricity } \\
\text { Generation }\end{array}$ & 10 & $0 \%$ \\
\hline & Other Process Use & 9 & $0 \%$ \\
\hline & $\begin{array}{l}\text { Process Cooling and } \\
\text { Refrigeration }\end{array}$ & 8 & $0 \%$ \\
\hline & Other Facility Support & 7 & $0 \%$ \\
\hline \multirow[t]{4}{*}{ Commercial } & Space Heating & 637 & $25 \%$ \\
\hline & Water Heating & 83 & $3 \%$ \\
\hline & Other & 61 & $2 \%$ \\
\hline & Cooking & 43 & $2 \%$ \\
\hline Power & Electricity generation & 526 & $21 \%$ \\
\hline Unclassified & Unclassified & 251 & $10 \%$ \\
\hline \multicolumn{2}{|c|}{ Total for all sectors } & 2537 & $100 \%$ \\
\hline
\end{tabular}

Next, the research team compiled data on energy efficient technology measures applicable to many of the supply chain fuel end uses that were characterized by the bottom-up modeling approach (including those summarized in Tables 2 and 3). Specifically, this data compilation effort focused on estimating the end use fuel savings achievable in a technical feasibility sense through the adoption of a best practice energy efficiency measures. Then, the team applied the energy savings estimates to each fuel end use in the modeling framework and compared the results to the GHG emissions baseline to calculate GHG emission reduction potentials.

The case study considered key fuel end use efficiency measures applicable to commercial sector electricity and natural gas, industrial sector electricity, natural gas, coal, and petroleum, agricultural electricity and petroleum, and water treatment electricity. As such, the research team's analysis addressed fuel end uses responsible for a large fraction of the average U.S. household GHG footprint. However, there are additional energy efficient technology measures applicable to other IO sectors that were not addressed in this case study (e.g., transportation, mining, construction, and the energy industries). These measures could be included in future work.

Moreover, only best practice, currently available, and cost-effective technologies were considered. More aggressive savings may be realized through advanced and emerging technologies; such technologies could also be evaluated in the modeling framework in future studies.

Furthermore, the research team did not consider changes to behavior (e.g., turning off lights or purchasing fewer goods), changes to energy supply (e.g., installation of solar photovoltaic panels), non-energy GHG emission mitigation measures (e.g., reductions in landfill gas flaring), or changes to purchased products (e.g., buying recycled paper) in its case study. These are all clearly very important options for reducing one's GHG footprint, which could be explored in the modeling framework in future work.

By way of example, Tables 4 and 5 summarize the measure assumptions for commercial fuel end uses and industrial electricity end uses. The data in Table 4 represent best available measure savings estimates for the United States from two recent comprehensive studies of U.S. commercial building appliance energy efficiency potentials [17, 18]. For the industrial fuel end uses in the supply chain model, the research team developed aggregate energy saving estimates for bundles of best practice energy efficient technologies at the 3-digit IO sector level. 
Table 5 summarizes the energy savings estimates derived in this case study for energy efficient technology bundles related to industrial electricity use. The estimates for savings from motor systems are based on a comprehensive national industrial motor system inventory conducted by Xenergy [19], which included site visits within various industrial IO sectors. The energy savings estimates for industrial HVAC, refrigeration, and lighting systems were derived using technology measure data from the U.S. DOE's Industrial Assessment Center database [20].

Energy efficiency measures were also compiled for thermal industrial end uses processes (i.e., end uses of natural gas, coal, and petroleum), electricity and petroleum end uses in the agricultural sector, and electricity end uses in the water treatment sector.

TABLE 4: COMMERCIAL TECHNOLOGY MEASURE ENERGY SAVINGS ASSUMPTIONS

\begin{tabular}{|c|c|c|}
\hline End Use & Technology Measure & Savings \\
\hline \multicolumn{3}{|c|}{ Electricity } \\
\hline Computers & $\begin{array}{l}\text { ENERGY STAR PCS and monitors, power } \\
\text { management enabled }\end{array}$ & $60 \%$ \\
\hline Cooking & $\begin{array}{l}\text { ENERGY STAR dishwashers, fryers, hot } \\
\text { food holding cabinets }\end{array}$ & $32 \%$ \\
\hline Cooling & Improved HVAC systems and controls & $48 \%$ \\
\hline Lighting & $\begin{array}{l}\text { T-8 lamps with electronic ballasts, } \\
\text { occupancy controls, daylight dimming, } \\
\text { improved lighting design }\end{array}$ & $25 \%$ \\
\hline $\begin{array}{l}\text { Office } \\
\text { Equipment }\end{array}$ & ENERGY STAR copiers and printers & $25 \%$ \\
\hline Other & $\begin{array}{l}\text { More efficient motors in ceiling fans, } \\
\text { pool pumps, other applications }\end{array}$ & $35 \%$ \\
\hline Refrigeration & $\begin{array}{l}\text { High efficiency upgrades to walk-in and } \\
\text { reach-in coolers and freezers, ice } \\
\text { machines, etc. }\end{array}$ & $38 \%$ \\
\hline Space Heating & Improved HVAC systems and controls & $39 \%$ \\
\hline Ventilation & Improved HVAC systems and controls & $45 \%$ \\
\hline \multicolumn{3}{|c|}{ Natural Gas } \\
\hline Space Heating & $\begin{array}{l}\text { Improved shell, HVAC systems, and } \\
\text { controls }\end{array}$ & $47 \%$ \\
\hline Water Heating & $\begin{array}{l}\text { Higher efficiency storage and } \\
\text { instantaneous units }\end{array}$ & $10 \%$ \\
\hline Other & $10 \%$ reduction in miscellaneous gas use & $12 \%$ \\
\hline Cooking & $\begin{array}{l}\text { ENERGY STAR fryer and steamer; more } \\
\text { efficient broilers, griddles and ovens }\end{array}$ & $31 \%$ \\
\hline
\end{tabular}

Table 5: Industrial technology measure Electricity savings assumptions

\begin{tabular}{|c|c|c|c|c|}
\hline \multirow[b]{2}{*}{200210 sector(s) } & \multicolumn{4}{|c|}{ Electricity } \\
\hline & $\begin{array}{l}\text { Motor } \\
\text { systems }\end{array}$ & HVAC & $\begin{array}{l}\text { Refriger- } \\
\text { ation }\end{array}$ & Lighting \\
\hline $311,312:$ Food $\&$ beverage & $12 \%$ & $14 \%$ & $15 \%$ & $16 \%$ \\
\hline 313, 314: Textiles & $14 \%$ & $13 \%$ & $10 \%$ & $16 \%$ \\
\hline 315: Apparel & $14 \%$ & $14 \%$ & $14 \%$ & $16 \%$ \\
\hline 316: Leather products & $12 \%$ & $10 \%$ & $10 \%$ & $16 \%$ \\
\hline 321: Wood products & $9 \%$ & $8 \%$ & $27 \%$ & $16 \%$ \\
\hline 322: Paper & $14 \%$ & $25 \%$ & $15 \%$ & $16 \%$ \\
\hline 323: Printing & $12 \%$ & $9 \%$ & $14 \%$ & $16 \%$ \\
\hline 324: Petroleum and coal & $20 \%$ & $15 \%$ & $15 \%$ & $16 \%$ \\
\hline 325: Chemicals & $16 \%$ & $14 \%$ & $15 \%$ & $16 \%$ \\
\hline 326: Plastics \& rubber & $15 \%$ & $10 \%$ & $21 \%$ & $16 \%$ \\
\hline 327: Nonmetallic mineral & $15 \%$ & $7 \%$ & $25 \%$ & $16 \%$ \\
\hline 331: Primary metals & $12 \%$ & $13 \%$ & $14 \%$ & $16 \%$ \\
\hline 332: Fabricated metals & $16 \%$ & $11 \%$ & $17 \%$ & $16 \%$ \\
\hline 333: Machinery & $15 \%$ & $10 \%$ & $6 \%$ & $16 \%$ \\
\hline 334: Computer \& electronics & $23 \%$ & $7 \%$ & $11 \%$ & $16 \%$ \\
\hline 335: Electrical equipment & $13 \%$ & $9 \%$ & $21 \%$ & $16 \%$ \\
\hline 336: Transportation equip & $15 \%$ & $9 \%$ & $20 \%$ & $16 \%$ \\
\hline 337: Furniture & $13 \%$ & $10 \%$ & $9 \%$ & $16 \%$ \\
\hline 339: Miscellaneous & $15 \%$ & $7 \%$ & $5 \%$ & $16 \%$ \\
\hline
\end{tabular}

The total GHG emission reduction potential associated with the adoption of the best practice supply chain energy efficient

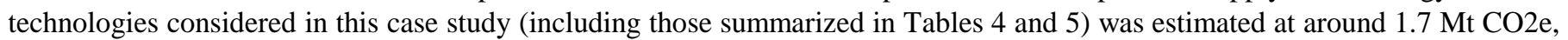
or around $13 \%$ of the total estimated 2002 supply chain GHG emissions.

Policy measures for increasing the adoption of efficient supply chain technologies include government and private sector green purchasing programs that give preferential treatment to suppliers who demonstrate best practice energy efficiency (for example, demonstrated by ENERGY STAR certification of commercial and industrial buildings) and product carbon footprint labels and standards. The latter policy measure has received much attention in recent years as a market based mechanism to drive superior supply chain performance, with a notable example being the Carbon Trust's Carbon Reduction Label [21].

A breakdown of supply chain GHG emissions reduction potential by end use measure type is offered in Figure 2. Results are categorized by major supply chain IO sector category (industrial, commercial, agricultural, and water treatment) and fuel end use measure category. Over one-half of the estimated supply chain GHG emissions reduction potential is associated with the top eight measure categories, which include efficiency upgrades to commercial electrical and natural gas end uses and industrial coal end uses.

Roughly one-half (900 kg CO2e) of the estimated supply chain potential is attributable to the commercial building measures considered in the case study; of these measures, technology upgrades to commercial HVAC and lighting systems are expected to lead to the greatest emissions reductions. The industrial measures considered in this case study account for around $40 \%$ (700 kg $\mathrm{CO} 2 \mathrm{e}$ ) of the estimated supply chain potential. The greatest reductions in the industrial sector were expected to come from efficiency upgrades to facility process heating, steam, and motor systems. 


\section{LIMITATIONS}

The general IO-based approach used for supply chain modeling in this project has several benefits, including the ability to model complex life-cycle systems in simple and efficient manner and the ability to estimate average life-cycle impacts for a wide variety of different product groups and types of services.

However, there are a number of key limitations to this method, which have been discussed extensively in the literature (see for example [4]). In particular, there are several limitations that are important caveats to the modeling framework presented in this paper.

First, the IO benchmark total requirements data used to estimate economy-wide transactions reflect U.S. economic infrastructures and supply chain technologies as of 2002. The implication is that the supply chain modeling framework developed in this project reflects static transactions that may lose relevance to current supply chains over time.

Second, the method is only capable of estimating average fuel end uses and GHG emissions for a given IO sector as a whole. For IO sectors with heterogeneous product outputs (e.g., the frozen food IO sector), the method provides fuel end use and GHG emissions estimates that are averaged across all goods or services produced by that IO sector. However, the method cannot estimate fuel end use and GHG emissions specific to any product within that IO sector (e.g., frozen blueberries).

Third, the method relies on many different data from a diversity of different sources. Thus, the parameter and modeling uncertainties associated with the method are significant and should be explored in future work.

Lastly, the fuel use, fuel end use, and GHG emissions coefficients employed in this study are based on average U.S. conditions for each IO sector. In reality, the supply chains for goods and services consumed in the United States extend across the globe. There is a growing research effort aimed at developing multi-regional input-output (MRIO) models to disaggregate U.S. supply chain transactions by country of origin (see for example [1]). The development of such MRIO models is a complicated process that was beyond the scope of this project. Thus, a limiting feature of the modeling framework discussed in Section II is that all estimates reflect "made in the U.S.A" conditions when in fact global supply chains are required.

\section{V.CONCLUSIONS}

The fuel end use modeling approach presented in this paper can allow energy and policy analysts to better understand the underlying technologies and processes contributing to the supply chain energy and GHG footprints of goods and services. As such, this modeling approach can help analysts and policy makers assess a wide range of technology options for reducing supply chain footprints in a discrete, bottom-up fashion.

The case study results shed light on some of the most important efficient technology opportunities for reducing the supply chain GHG footprints of U.S. households. Knowledge of the most significant end use efficiency opportunities can help inform policy initiatives aimed at reducing such supply chain energy and GHG footprints. For example, green purchasing programs could consider giving preferential treatment to supply chain partners with efficient commercial and industrial buildings, as approximated by the presence of high efficiency HVAC, lighting, process heating, steam, and motor systems in those buildings. Such information could be quickly and easily verified through facility audits or documentation of the installation of best practice equipment. 


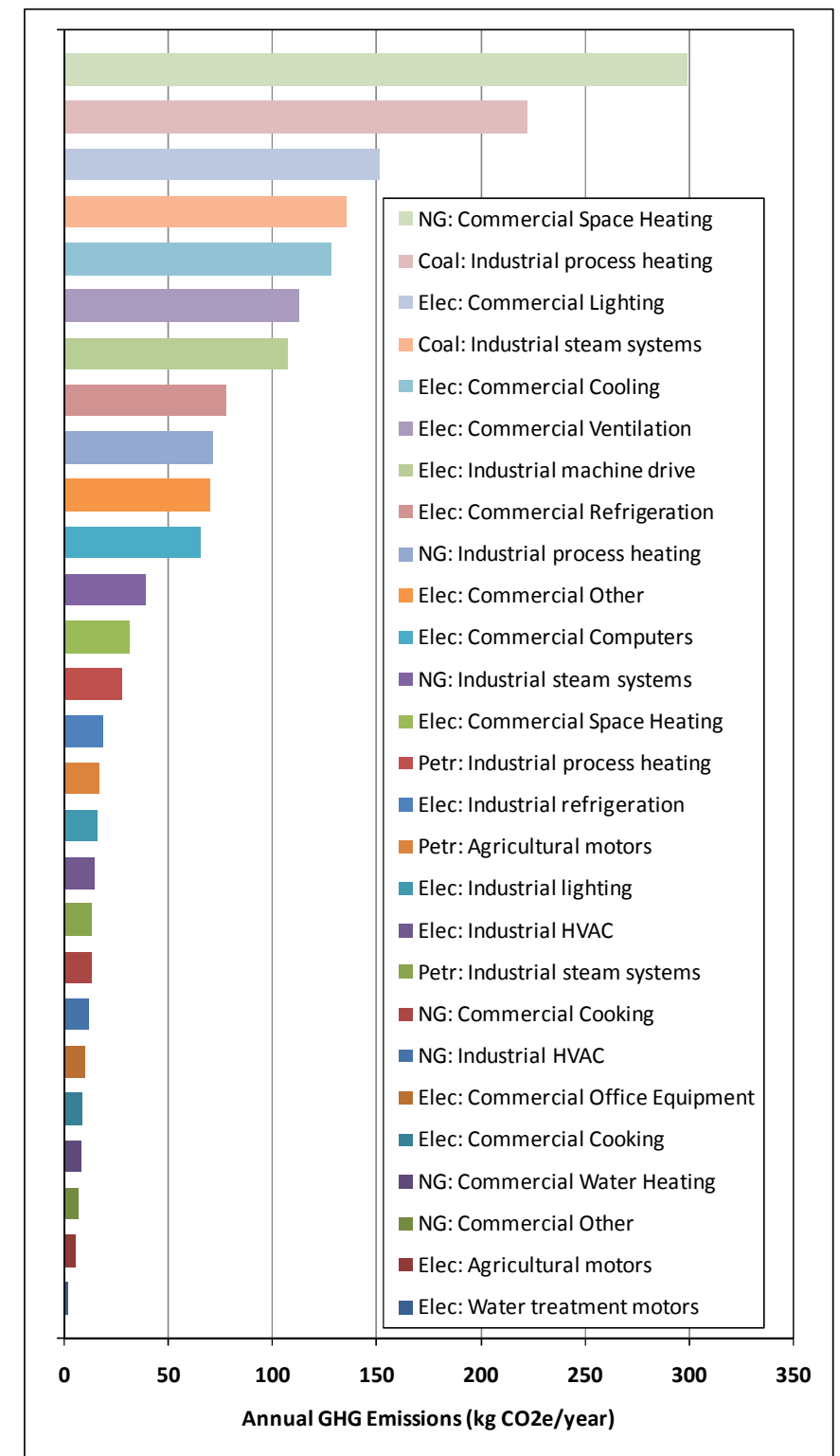

FIGURE 2: ESTIMATED SUPPLY CHAIN GHG EMISSIONS REDUCTION POTENTIAL BY SECTOR AND FUEL END USE MEASURE

\section{REFERENCES}

[1] Weber, C.L., and H.S. Matthews (2008). "Quantifying the global and distributional aspects of American household carbon footprint." Ecological Economics, Volume 66, Issues 2-3, Pages 379-391.

[2] United States Environmental Protection Agency (EPA) (2008). Inventory of U.S. Greenhouse Gas Emissions and Sinks: 1990 - 2006. Washington, D.C. USEPA \#430-R-08-005.

[3] Herendeen, R. A. and C. W. Bullard (1975). "The Energy Cost of Goods and Services," Energy Policy, 3:4, 268-278.

[4] Hendrickson, C.T., Lave, L.B., and H.S. Matthews (2006). Environmental Life Cycle Assessment of Goods and Services: An Input-Output Approach. Resources for the Future Press, Washington, D.C.

[5] Carnegie Mellon University (CMU) (2008). Economic Input-Output Life Cycle Assessment (EIO-LCA) model. Available at: http://www.eiolca.net/

[6] United States Bureau of Economic Analysis (BEA) (2008). 2002 Benchmark Input-Output Data. United States Department of Commerce, Washington, D.C. Available at: http://www.bea.gov/industry

[7] Weber, C.L., and H.S. Matthews (2009). Personal email communication with Chris Weber and Scott Matthews of Carnegie Mellon University. January 2009.

[8] United States Department of Energy (DOE) (2005). 2002 Manufacturing Energy Consumption Survey. Energy Information Administration, Washington, D.C. Available at: http://www.eia.doe.gov/emeu/mecs/ 
[9] United States Department of Energy (DOE) (2008). 2003 Commercial Building Energy Consumption Survey. Energy Information Administration, Washington, D.C. Available at: http://www.eia.doe.gov/emeu/cbecs/

[10] Brown, E., and R.N. Elliott (2005a). On-Farm Energy Use Characterizations. American Council for an Energy-Efficient Economy, Washington, D.C. Report IE052.

[11] Brown, R., Galitsky, C., Green, F.B., and C.D. Whitehead (2007). Energy Efficiency Improvement and Cost Saving Opportunities for the Municipal Drinking Water Industry: An ENERGY STAR Guide for Energy and Plant Managers. Lawrence Berkeley National Laboratory, Berkeley, California.

[12] Lawrence Berkeley National Laboratory (2009). Industrial Energy Analysis Publications. http://industrial-energy.lbl.gov/

[13] Intergovernmental Panel on Climate Change (IPCC) (2008).Emission Factor Database. Available at: http://www.ipcc-nggip.iges.or.jp/EFDB/main.php

[14] United States Environmental Protection Agency (EPA) (2004). Inventory of U.S. Greenhouse Gas Emissions and Sinks: 1990-2002. Washington, D.C.

[15] Masanet, E., K.J. Kramer, G. Homan, R.E. Brown, and E. Worrell (2009). Assessment of Household Carbon Mitigation Potentials. Lawrence Berkeley National Laboratory, Berkeley, California.

[16] United States Bureau of Labor Statistics (2008). Consumer Expenditure Survey, Online Statistics. Washington, D.C. Available at: http://www.bls.gov/cex/

[17] Rosenquist, G., McNeil, M., Iyer, M., Meyers, S., and J. McMahon (2006). "Energy Efficiency Standards for Equipment: Additional Opportunities in the Residential and Commercial Sectors." Energy Policy 34:3257-3267.

[18] Brown, R., Borgeson, S., Koomey, J., and P. Biermayer (2008). U.S. Building-Sector Energy Efficiency Potential. Lawrence Berkeley National Laboratory, Berkeley, California. LBNL-1096E.

[19] Xenergy (2002). United States Industrial Electric Motor Systems Market Opportunities Assessment. Technical Report Prepared for the United States Department of Energy, Industrial Technologies Program, Washington, D.C.

[20] United States Department of Energy (DOE) (2008). Industrial Assessment Centers Database. Available at: http://iac.rutgers.edu/

[21] Carbon Trust (2008). Carbon Reduction Label. London, England, United Kingdom. Available at: http://www.carbon-label.com/ 